Bangladesh J. Bot. 37(2): 173-178, 2008 (December)

\title{
MARINE ALGAE OF THE ST. MARTIN'S ISLAND, BANGLADESH. VI. NEW RECORDS OF SPECIES OF THE GENUS KALLYMENIA J. AG. (RHODOPHYTA)
}

\author{
Abdul Aziz, A.K.M. Nurul Islam AND A. Jahan \\ Department of Botany, University of Dhaka, Dhaka 1000, Bangladesh
}

Key words: Seaweeds, Marine algae, Kallymenia spp., St. Martin's Is., Bangladesh

\begin{abstract}
Four species of the genus Kallymenia J. Ag. such as K. cribrosa Harvey, K. rosea Womersley \& Norris, $K$. rubra Womersley \& Norris $K$. tasmanica Harvey have been reported for the first time from St. Martin's Island, Bangladesh.

\section{Introduction}

After the publication of marine algae of Bangladesh by Islam (1976), about 35 taxa of marine red algae have so far been reported (Islam and Aziz 1982, Islam and Aziz 1987, Aziz 1997, Islam et al. 2002, Aziz et al. 2002a, Aziz et al. 2002b, Aziz 2008). Many collected specimens are yet to be worked on. During the survey of collections made from the St. Martin's Island in 1997, the authors came across some species of the genus Kallymenia J. Ag., hitherto not reported from Bangladesh. On examination, four species have been identified and these are illustrated in the present account.
\end{abstract}

\section{Materials and Methods}

Four red macro-algae collected as drifted and or live, two from south-east and two from north-west during fourth week of March 1997 have been studied. The samples were preserved in $5 \%$ formalin in the sea water. Harberia were prepared within a few days of collections and photographs were taken.

\section{Results and Discussion}

Red macro-algal genus Kallymenia J. Ag. collected from the St. Martin's Is., Bangladesh, on examination was found to be composed of four species. The genus Kallymenia and the four species are described and illustrated below.

\section{Order: Cryptonemiales; Family: Kallymeniaceae}

\section{Genus: Kallymenia J. Ag.}

Thallus expanded, sub-simple or divided in to broad lobes, without mid-rib or veins, beautifully-membranous, formed internally of three layers: an inner layer of elongated, branched, anastomosing filaments called medulla which is bounded on both sides by a layer of large triangular to polygonal cells called sub-cortex, followed by a dense layer of smaller, rounded to short cylinder chromatophore bearing assimilatory cells to the surface called outer-cortex; sporangia scattered in the cortical layer, tetrapartite, on separate thalli; cystocarps wart-like, sunk in the thallus or projecting as swollen spots, surrounded by rhizoidal outgrowths from the neighbouring cells. 
1. Kallymenia cribrosa Harvey

(Fig. 1a-c)

(Womersley and Norris 1971, 4, Fig. 77)

Thallus subsessile, about $30 \mathrm{~cm}$ high, probably as broad as high, expanded into a nearly single foliose body (margins torn off); perforations numerous and scattered mostly on the peripheral part of the thallus; light blood red in colour, gelatinous but fairly firm when fresh; cortex consists of 3 layers of cells, outermost layer of cells elongated followed by rounded cells; outer cortical cells 7 $10 \mu \mathrm{m}$ in length, inner cortical cells $12-20 \mu \mathrm{m}$ broad; innermost cortical cells large and triangular; medulla with elongated loosely arranged cells. Cystocarps massive, $170-300 \mu \mathrm{m}$ broad, immersed.

It also resembles $K$. perforata J. Ag., a species from Ceylon having less number of perforations (Womersley et Norris 1971, 5)

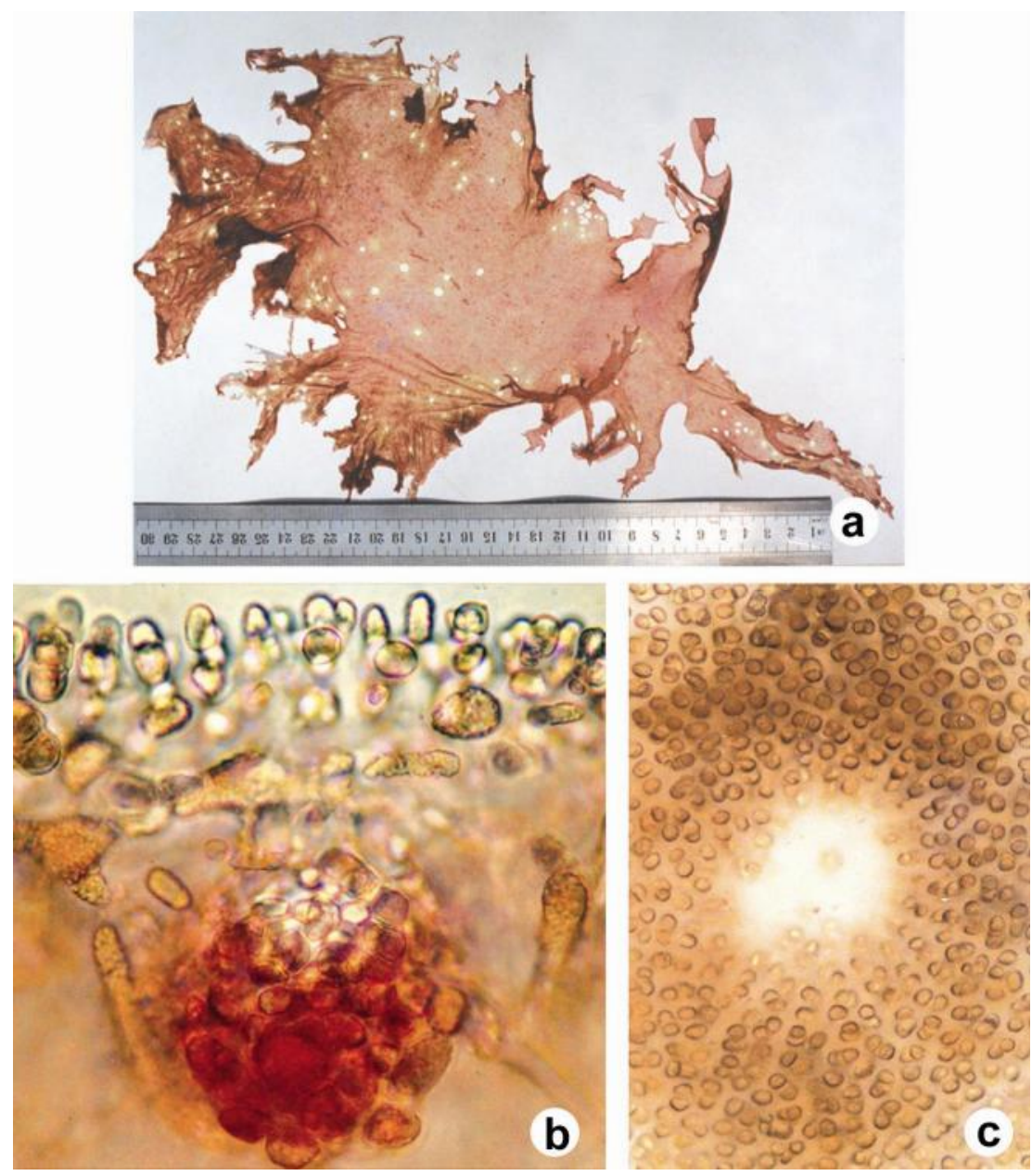

Fig. 1a-c. Kallymenia cribrosa. (a) Herberium of whole thallus, partially disintegrated. (b) Section of the thallus showing a cystocarp. (c) Surface view of the thallus with a perforation.

Distribution: Collected from North-west coast of St. Martin's Is., Bangladesh, on 22 March 1997, as drifted form, abundant; South Australia to Flinders, Victoria and around Tasmania., Type locality: Fremantle, West Australia. Rapidly disintegrate as drift. 
2. Kallymenia rosea Womersley et Norris 1971

(Fig. 2a-c)

(Womersley and Norris 1971, 9, Figs., 19, 82)

Thallus foliose, $30 \mathrm{~cm}$ or more high, $50-60 \mathrm{~cm}$ wide, pink-red in colour, stipe short which produces as many as five short stalked wide leafy branches; branches delicate and mucilaginous, lobed with uneven and undulate margins; tongue-like propagules arise from the margins of leafy branches; herbarium materials corrugated; thallus $50-113 \mu \mathrm{m}$ thick, cortex 2 layered, compact with spheroidal epidermal or outer cortical cells, 7-17 $\mu \mathrm{m}$ in diam., inner cortical cells spheroidal to triangular; medulla with loosely arranged hyphae-like cells. Cystocarps wart-like, $250-300 \mu \mathrm{m}$ broad, numerous and scattered on both sides of the thallus just below the cortex. Tetraspores not found.

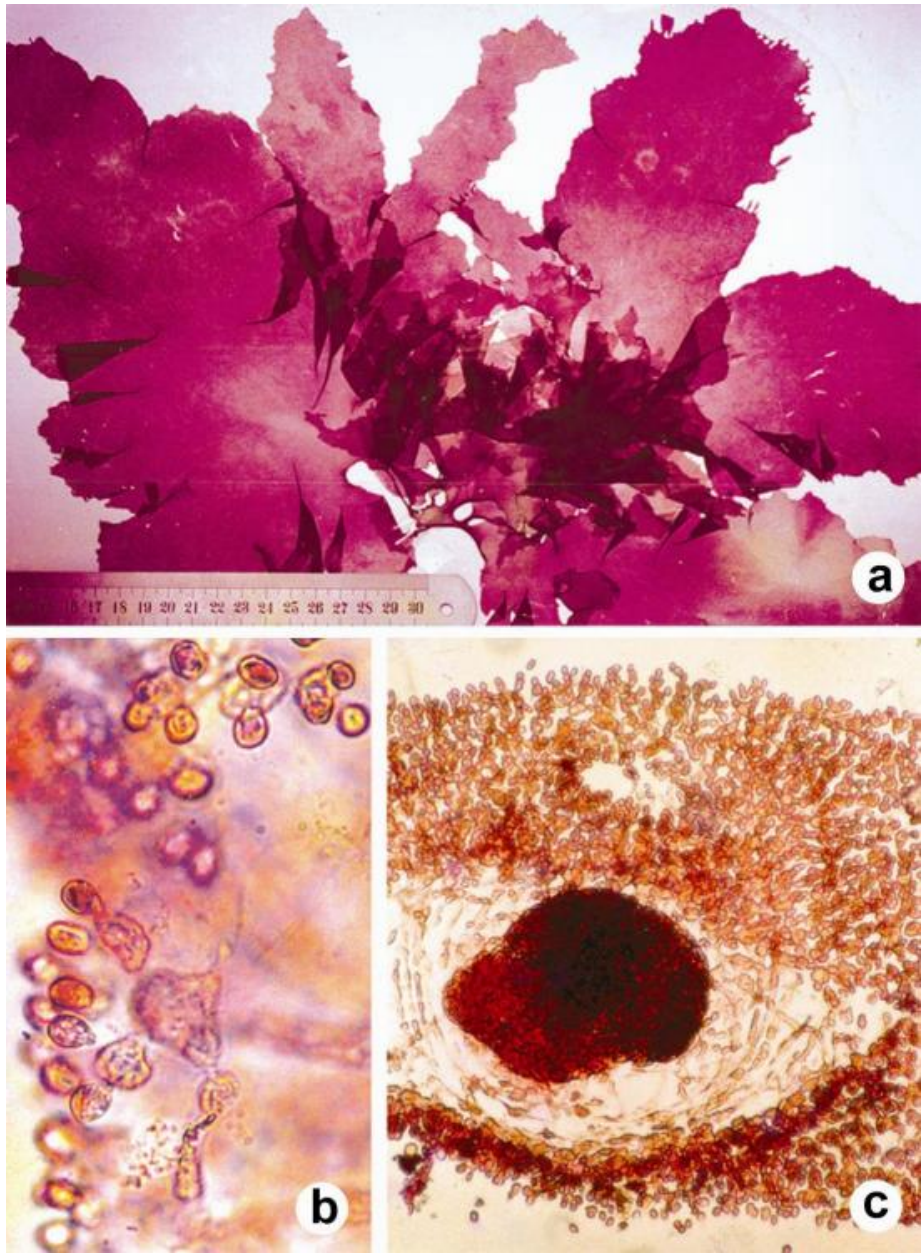

Fig. 2a-c. Kallymenia rosea. (a) Herberium of whole thallus. (b) Section of the thallus showing cortical cells. (c) Section of the thallus showing a cystocarp.

Distribution: Collected from North-west coast of St. Martin's Is., Bangladesh, on 22 March 1997, as drifted form, abundant; Botany Bay and Port Stephens, N.S.W. Type locality: Botany Bay, N.S.W. 
3. Kallymenia rubra Womersley et Norris 1971

(Fig. 3a-c)

(Womersley and Norris 1971, 13, Fig. 86)

Thallus about $30 \mathrm{~cm}$ high, as broad as high, expanded into fan-shaped blades, margins moderately wavy; perforations few and scattered; blood-red in colour, gelatinous but fairly firm when fresh; cortex consists of 3 - 4 layers of cells, outer two layer of cells ovoid to rounded, 5 - 7 $\mu \mathrm{m}$ in diam., followed by also ovoid to rounded larger cells; inner cortical cells triangular to polygonal, $10-20 \mu \mathrm{m}$ broad which perhaps act as the tetrasporangial mother cells, medulla loosely arranged; tetrasporangia scattered among the cortical cells, cruciately divided; tetraspores 15 - $18 \mu \mathrm{m}$ long, 7.5 - $10 \mu \mathrm{m}$ broad.
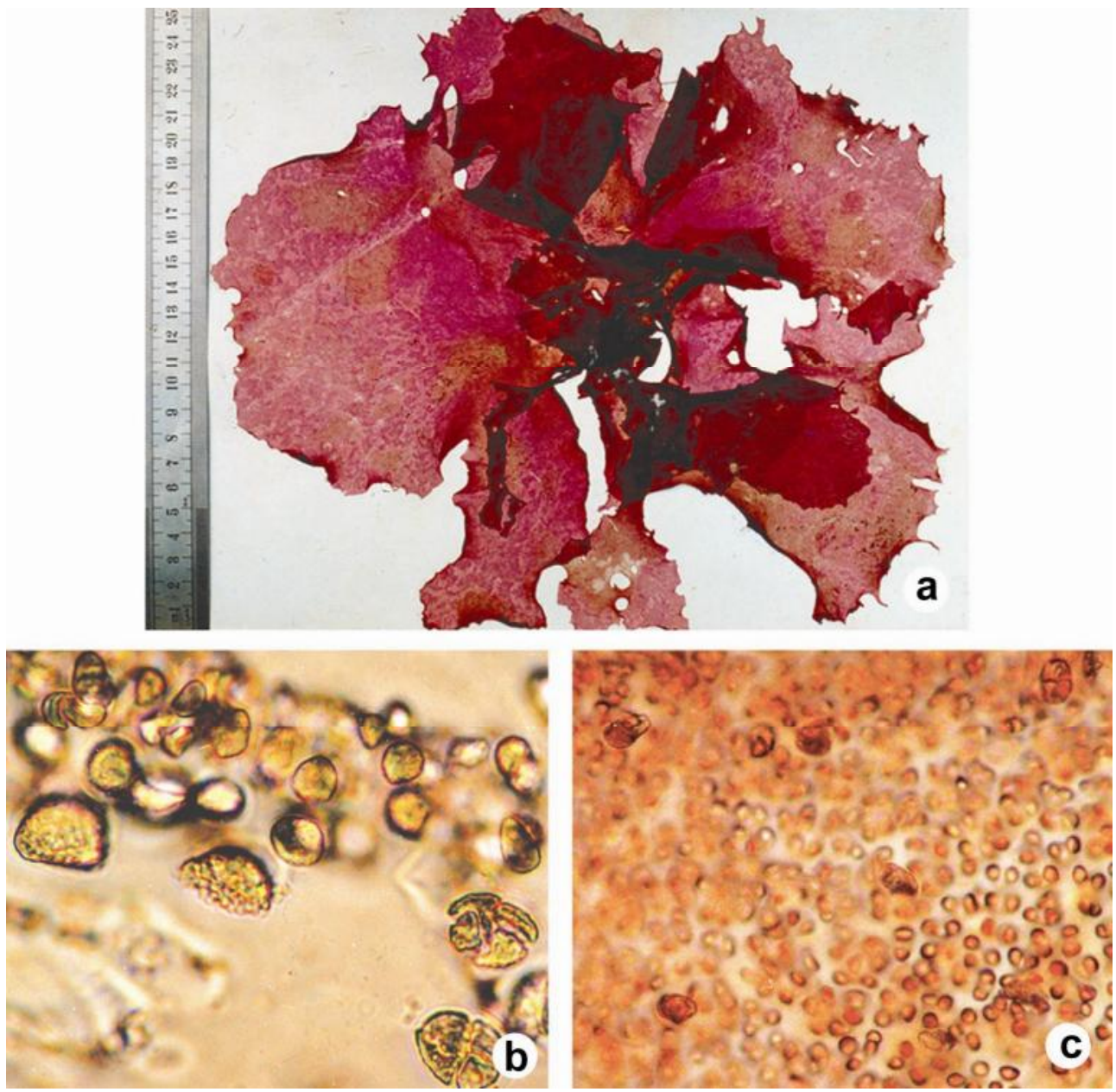

Fig. 3a-c. Kallymenia rubra. (a) Herbarium of whole thallus. (b) Section of the thallus showing cruciate tetraspores (lower right). (c) Surface view of the thallus with tetrasporangia.

Distribution: Collected from South-East coast of St. Martin's Is., Bangladesh, on 24 March 1997, both drifted and living forms, abundant; Elliston, South Australia \& Waldegrave I, near Elliston. Type locality: Elliston, South Australia, drifted. 
4. Kallymenia tasmanica Harvey

(Fig. 4a-c)

(Womersley and Norris 1971, 12, Figs. 21, 84)

Thallus about $35 \mathrm{~cm}$ high and wider than the height, large expanded into several broad blades with short stipe, margins moderately wavy, perforations large and few (many for small ones); short adventitious marginal branches common; rosy-red in colour, gelatinous but fairly firm when fresh; cortex consists of 3 - 4 layers of cells, outer two layer of cells cylindric to conical, $10-14$ $\mu \mathrm{m}$ long, $5-7 \mu \mathrm{m}$ in diam., followed by triangular to polygonal inner cortical cells, $8-18 \mu \mathrm{m}$ broad which perhaps act as the tetrasporangial mother cells, medulla loosely arranged; tetrasporangia scattered among the cortical cells, cruciately divided; tetraspores 13 - $15 \mu \mathrm{m}$ long.
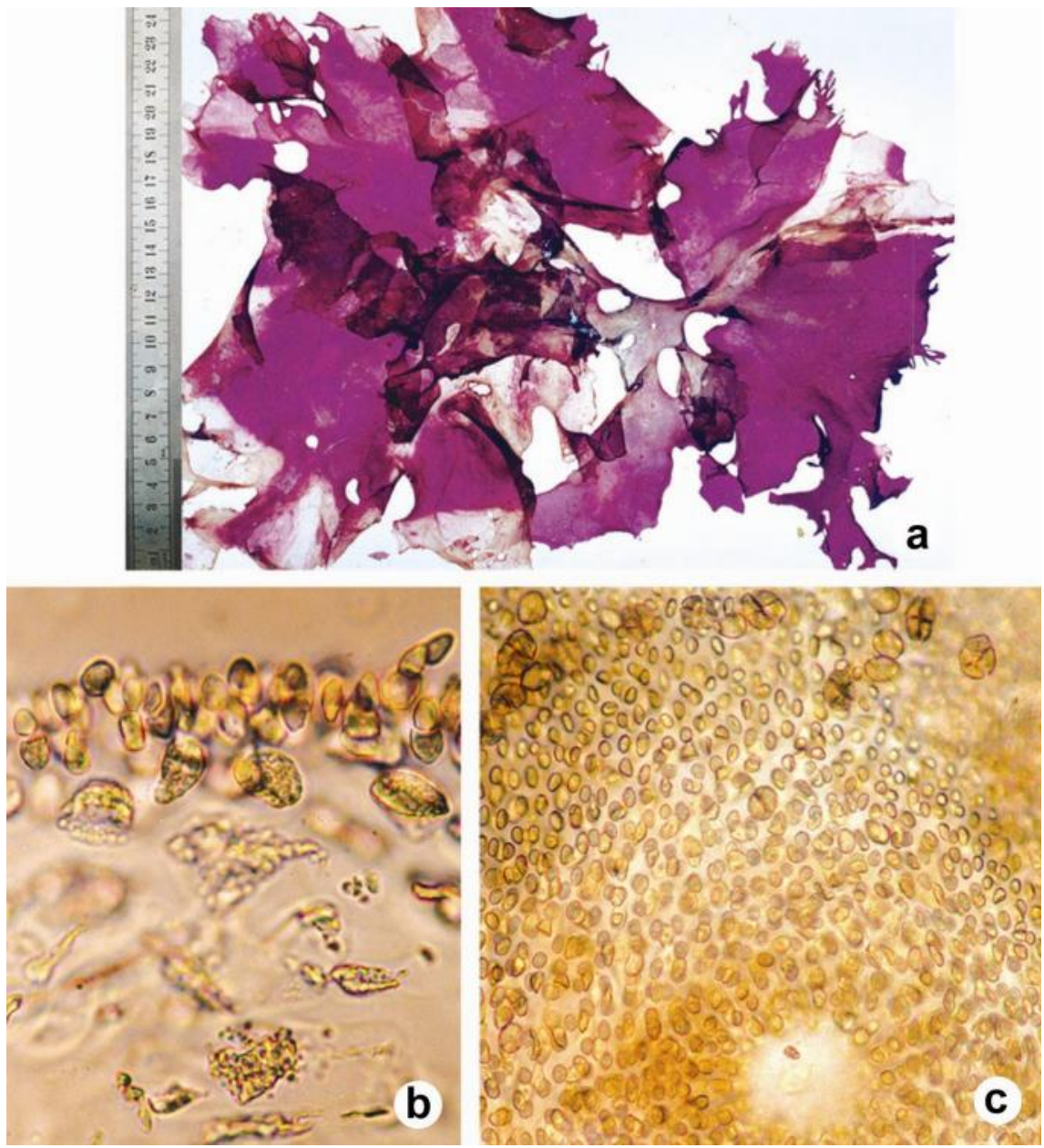

Fig. 4a-c. Kallymenia tasmanica. (a) Herberium of whole plant. (b) Section of the thallus showing sub cortical tetrasporangia. (c) Surface view of the thallus showing tetraporangia and tetraspores, and a small perforation in the foreground.

Distribution: Collected from South-East coast of St. Martin's Is., Bangladesh, on 24 March 1997, as drifted and living forms, abundant from St. Vincent Gulf, South Australia to Western Port, Victoria. Type locality: Georgetown, Tasmania. 


\section{References}

Aziz A. 1997. Peyssonelia polymorpha (Zonard.) Schmitz (Rhodophyta) newly recorded from St. Martin's Island, Bangladesh. Bangladesh J. Plant Taxon. 4(1): 81-83.

Aziz A. 2008. Marine algae of St. Martin's Is., Bangladesh. V. Antithamnionella floccossum (Müller) Whittick. Bangladesh J. Plant Taxon. 15(1): 63-65.

Aziz A., A.K.M. Nurul Islam and A. Jahan. 2002a. Marine algae of St. Martin's Is., Bangladesh. III. Red algae. J. Asiat. Soc. Bangladesh, Sci. 28(1): 63-70.

Aziz A., A.K.M. Nurul Islam and A. Jahan. 2002b. Marine algae of St. Martin's Is., Bangladesh. IV. New records of red algae. Bangladesh J. Bot. 31(2): 113-116.

Islam A.K.M.N. 1976. Contribution to the study of the marine algae of Bangladesh. Bibliotheca Phycologica 19: 1-253.

Islam A.K.M.N. and A. Aziz. 1982. Addition to the list of the marine algae of St. Martin's Is., Bangladesh. II. Brown, red and blue-green algae. Nova Hedwigia 36: 643-657.

Islam A.K.M.N. and A. Aziz. 1987. Addition to the list of the marine algae of St. Martin's Is., Bangladesh. III. Red algae. Nova Hedwigia 45: 211-221.

Islam A.K.M.N., A. Aziz and A. Jahan. 2002. Marine algae of St. Martin's Is., Bangladesh. II. New records of red algae. Bangladesh J. Bot. 31(1): 23-28.

Womersley H.B.S. and R.E. Norris. 1971. The morphology and taxonomy of Australian Kallymeniaceae (Rhodophyta). Aust. J. Bot. Supl. No. 2: 1-62. 